\title{
Modeling Android-based Camcorder Simulator Application As A Learning Media for Cinematography Courses
}

\author{
Heri Triluqman Budi Santoso a ${ }^{a}$ Mulyoto $^{b}$, Leo Agung Sutimin ${ }^{c}$ \\ ${ }^{a}$ Master Student of Education Technology, Sebelas Maret University, Surakarta, Indonesia \\ ${ }^{\mathrm{b}}$ Faculty of Teacher Training and Education, Sebelas Maret University, Surakarta, Indonesia \\ ${ }^{\mathrm{c}}$ Faculty of Teacher Training and Education, Sebelas Maret University, Surakarta, Indonesia \\ Corresponding e-mail: heritl@,student.uns.ac.id
}

\begin{abstract}
Integrating information and communication technology (ICT) in the learning process continues to evolve with various patterns and strategies, grouped into (1) e-Learning system, the process of learning that utilizes electronic devices and digital media, and (2) m- Learning, or mobile learning, the process of learning that utilizes mobile communication technology and devices. The rapid development of mobile devices, relatively easy operations, and more affordable prices, is a supporting factor in the widespread use of mobile learning to become a new alternative of learning media. These conditions encourage the formation of learning paradigm that can be done anytime and anywhere. The aim of the research is to develop the design/model of an Android-based Camcorder Simulator Application for the students of cinematography courses majoring education technology of education faculty in Semarang State University. This research method refers to the research and development (R\&D) proposed by Borg and Gall (in Sukmadinata, 2016) with some modifications that have been developed by Sukmadinata. Withal, the research procedures used in this study focus on the development stages of application model/design. This step includes the following steps; (1) Model development (product design), (2) Design validation, and (3) Design revisions. The results of this study indicate that the process of developing an android-based camcorder simulator application model is done through the steps according to the research procedures, beginning with requirement analysis, then compiling competency map, material map, the main point of media content (GBIM), material descriptions (JM), flowchart and script, then design validation and product revision. Modeling camcorder simulator application is also ready for further stage of research and development. The use of an android-based camcorder simulator application is demanded in the learning process of cinematography course, especially the engineering material and the shooting procedure as it can assist students to be autonomous learners.
\end{abstract}

Keywords: Model Design, Camcorder Simulator, Android.

\section{INTRODUCTION}

Utilization of information and communication technology (ICT) in education continues to grow in various patterns and strategies. Generally, it can be classified into 2 (two) groups, namely: (1) e-Learning system, as a form of learning that utilizes electronic devices and digital media, and (2) m-learning (mobile learning), as a form of learning that specifically utilizes the device and mobile communication technology. Nowadays, the use or application of mobile learning is a new tendency in learning, forming a learning paradigm that can be done whenever and wherever more widespread. The factors contributing, among other things, are the very high rate of mobile device development, the relatively easy level of usage, and the more affordable price of the device, compared to personal computer devices (Rusman, 2013).

The term of mobile learning refers to the use of mobile and mobile information technology devices, such as mobile phones, in learning. The important capabilities that must be possessed by mobile learning devices include the capability to connect to other equipment (especially computers), the capability to provide learning information and the capability to create communication between teachers and learners. Mobile learning is a smart-picturesque learning because learners can easily access learning materials, referrals and applications related to learning, whenever and wherever the place is. Of course, it will be able to increase the concentration on learning materials, and can encourage the motivation of learners to do lifelong learning.

Based on data from wearesocial.sg website quoted on January 2014, the number of mobile devices users in Indonesia reached $281,963,665$. It shows a figure of $112 \%$ of the total population of Indonesia which reaches about 250 million people (Horwitz, 2014). The same source also mentioned that for this type of operating system, smartphone users in Indonesia mostly use Android system. Android is an operating system platform on mobile devices (such as smartphones/mobile phones) that are 
already widely used by various vendors. If you have not been able to develop applications or not interested in being a developer due to limited capabilities, we can utilize it as a user only. Moreover, various applications in the smartphone can be used as a learning resource for students, collegers or even the teachers (Urip, 2011). Android system developed by Google is an operating system which is also an open source. It enables others to contribute to their development. Just like Linux (operating system for computers), Android is also experiencing a very rapid growth.

The change and innovation of the field about ICT in the education world as mentioned above continues to grow. Some of the changes that occur are (a) easier to access and develop the learning resources, (b) the more varied choices of using and utilizing Information and Communication Technology (ICT) in learning, (c) the increasing contribution of media and multimedia in the learning process, (d) learning time becomes more flexible, (e) implementation of computer-based learning, (f) media utilization of video/television, e-learning, mobile learning, and e-library, and (g) online curriculum. These changes and innovations have enormous implications for the education world, namely changes in applied learning technology upgrades, changes in methods and learning models, and integrating ICT in the learning process (Rusman, 2013).

Furthermore, these changes demanding the world of education to innovate and develop creativity in learning activities. Many people are discussing updates in the learning process, but few of them are discussing solutions to the problem of contemporary learning. Adjustment of science to the rapid development of ICT fields in the hope of printing quality human resources is an unavoidable necessity. Educators are expected to integrate ICT in learning so that the quality of process and learning outcomes are better than before. Consequently, the improvement of the quality of Indonesian education can be achieved. This condition is also expected to occur in the process of learning in universities, especially for the study programs in LPTK (Institue of Teachers' Education) which is the place to educate and train prospective teachers.

Integration of ICT in learning in college determinately also requires adequate facilities and infrastructure, especially for lecture practices that directly require the equipment in the learning process. Equipment in adequate quantities both in terms of quality and quantity will certainly affect the student learning outcomes and determine the competencies to be achieved. An unideal condition for students of
Technology Study Program in State University of Semarang, especially for the pupils of the course of Cinematography of Learning. The number of equipment (video camera) is very limited in the number of students, making them takes longer time in learning to know and operate the video camera. The video camera is owned by the department of Technology Education laboratory of 6 units (4 units of Panasonic and 2 units of Sony) in comparison with 76 students of the subjects of cinematography lesson in 1 semester. With such conditions, to accelerate the learning process of students, it is necessary to develop a media that allows students to learn first before holding the video camera equipment directly. Therefore, this research has a goal to develop the design of camcorder-based simulator model for android for cinematography course of study of Education Technology in State University of Semarang.

\section{REVIEW OF LITERATURE}

The previous study that has been done and relevant to this research include the research conducted Permadi (2013) is a research application development of tingklik virtual simulation game and bali flute Android-based. In addition, Prameswari (2009) conducted a study on development of simulation application of multimedia-based car engine. Thereunto, the research established by Soemapraja (2014) about the development of stock trading simulation applications with sector rotation and linear programming. Another study was conducted by Pasarai (2010) on the development and application of reservoir simulators for simulation of gas percolation in a solvent-driven gas reservoir. These studies have similarities, that develop an application as a media simulation. However, from the various studies that exist, the researchers have not found research on simulation applications for learning media with video camera material yet. It is also one of the considerations of the research team proposed this research topic.

Other studies related to the development or use of android applications as a medium of learning has been widely implemented in recent years. Some of the research can be described as follows: (a) Purbasari (2013) conducting research on android application development as a medium of mathematics learning on three dimensional material for students of tenth graders in vocational high school; (b) Sambodo research (2014) about development of learning media of mobile learning (m-learning) based on android on human circulatory system material for high school students of senior high school; (c) 
Kusuma (2013) conducted research on mobile educational app designing 'learning chord piano for beginners' android-based; (d) another research was conducted by Sutanto (2013) with the title of educational application of "smart brain kids" android-based as a medium of learning for early childhood. These studies emphasize the use of android-based applications as a medium of learning. The developed application is a medium that can be used by the user to learn about something particular material. during this study related to the utilization of android applications, more to make children paud age to high school students / equal as the subject of his research.

\section{RESEARCH METHOD}

This research method refers to the research and development strategy proposed by Borg and Gall (in Sukmadinata, 2016) with some modifications that have been developed by Sukmadinata. In this article, the research procedure used focuses on the second stage, namely the model development stage. In this stage, the research includes the following steps: (1) Development model (product design), (2) Design validation, and (3) Design revision.

The research was conducted in the laboratory of Education faculty in State University of Semarang specifically in Education Technology Study Program, on MayJuly 2017, with 2nd semester students as a sample who still in year of 2016-2017 studying the course of cinematography of learning.

\section{RESEARCH RESULT AND DISCUSSION}

\subsection{Application Design Camcorder}

\section{Simulator}

\subsubsection{Requirement Analysis}

Based on the result of "Study of Needs of Developing Video Camera Android-based Simulator Software Application in Education Technology Study Program, Education faculty, State University of Semarang" which has been published before (Triluqman, 2017), it can be drawn conclusion in 2 (two) aspects, that is aspect of application requirement analysis and beginning ability of college students' aspect. In the aspect of the application needs to be developed, at least can be operated on a smartphone with minimal specifications such as: (1) Using the Android operating system, version 4.0 (Ice Cream Sandwich) or more, (2) camcorder simulator application that will be developed to operate maximally on a smartphone with less than 1 GB of RAM, and ROM less than 8 GB.

Table 4.1: Android version on student smartphone

\begin{tabular}{clc}
\hline NO & ANDROID VERSION USED & $\begin{array}{c}\text { \% USER } \\
\text { AMOUNT }\end{array}$ \\
\hline 1 & Android v7.0 Nougat & $3,9 \%$ \\
\hline 2 & Android v6.0 Marshmallow & $15,6 \%$ \\
\hline 3 & Android v5.0 - 5.1 Lollipop & $39 \%$ \\
\hline 4 & Android v4.4 Kitkat & $24,7 \%$ \\
\hline 5 & Android v4.1 - 4.3 Jelly Bean & 14,3 \\
\hline 6 & $\begin{array}{l}\text { Android v4.0 Ice Cream } \\
\text { Sandwich }\end{array}$ & $0 \%$ \\
\hline 7 & Android v3.0 - 3.2 Honeycomb & $1,3 \%$ \\
\hline 8 & $\begin{array}{l}\text { Android v2.3 Gingerbread } \\
\text { (dan/atau versi sebelumnya) }\end{array}$ & $3,9 \%$ \\
\hline
\end{tabular}

As for the related aspects of the student's beginning ability, it implies on the subjects to be embedded into the application, in order of priority scale mentioned as follows: (1) Dubbing images from video camera/camcorder to other video devices, (2) "Intelligent auto mode ", (3) settings menu, (4) image stabilizer function, (5) recording/play back settings, (6) memory card types, (7) use of menu screen, (8) connect video camera/camcorder to Computer/Laptop, (9) do manual recording, (10) recording with manual focus, (11) how to watch recording/picture on video camera/camcorder via Television, (12) install and remove camcorder video camera/camcorder, (13) good charging procedure, (14) memory card, (15) use/hold video camera/camcorder to record, (16) delete video/photo recording (17) using zoom in/out function, (18) and how to turn video camera/camcorder on/off.

Broadly speaking, the beginning ability of the students who are the participants of the course of cinematography learning can be seen in the following figure:

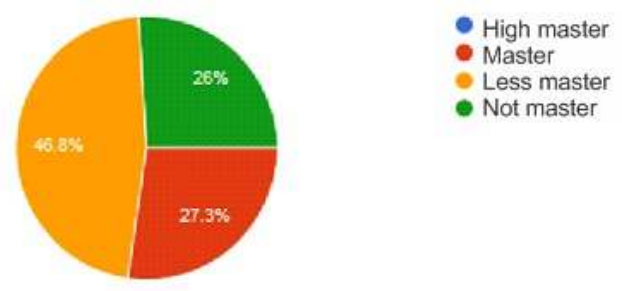

Figure 4.1: Student's beginning ability to use the settings menu on the camcorder

\subsubsection{Competency Map}

Competency Map is the goal to be achieved in learning. Competence to be achieved through this camcorder simulator application is the students master the techniques of shooting. The map of competence in application development as follows: 


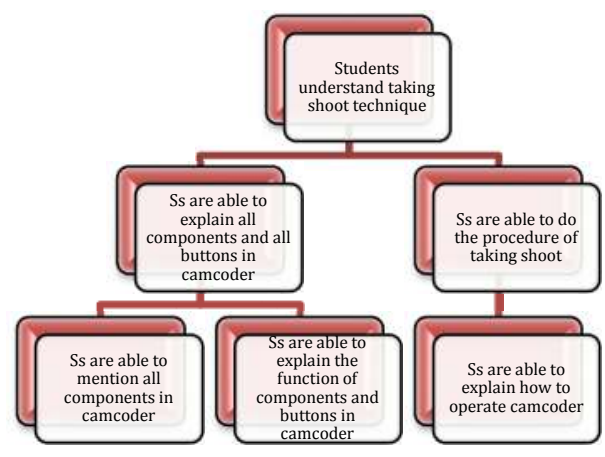

Figure 4.2: Compatibility map of camcorder simulator application

\subsubsection{Material Map}

The material map is a description of what material will be learned from the script and the program that will be created. The material that will be discussed in this application is the techniques of shooting with camcorder, along with derivative material, which can be seen in more detail in the following picture:

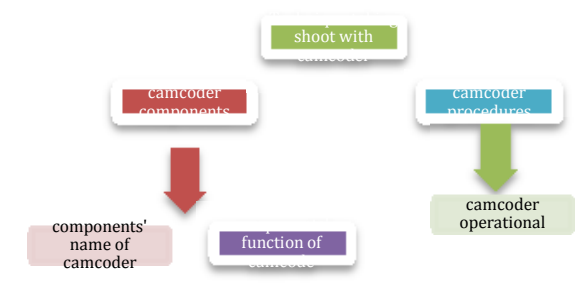

Figure 4.3: Camcorder simulator material application map

\subsubsection{GBIM}

GBIM is an abbreviation of "Garis Besar Isi Media"/ the Main Point of Media Content which contains a summary of the menu, the purpose / indicator, the material, the evaluation form and what media will be used in the script later. GBIM for this camcorder simulator application is compiled as an explanation of competency maps and existing material maps. The content in GBIM is also based on RPS (BCO/Lesson Plan) course of instructional cinematography.

Basically, the GBIM camcorder simulator application loads the following: (a) Menu: contains material items according to the material map, i.e the camcorder component and the shooting procedure with the camcorder, (b)
Objectives/Indicators: contain the competencies/indicators to be achieved in accordance with the competency map, i.e the student can explain the components (buttons) in the camcorder, as well as the students can take a shooting procedure, (c) Material: contains any material explanations to be discussed on the menu. On the component menu of the camcorder, it will discuss the material about the component names/menus on the camcorder along with its functions. While the shooting procedure with camcorder, focus on camcorder operational material, (d) Media: describes what media will be in each of these materials. In the camcorder simulator application, the media used more in the form of text, graphics, and video, (e) Description: contains the source/reference book when necessary in application development. In this study, the references use the manual book of one type of camcorder owned by the laboratory majoring in Education and Curriculum Education faculty, State University of Semarang.

In order to clarify the GBIM, it also compiles the material descriptions which are an explanation of the material columns at GBIM. In elaborated material, it presented the subject matter discussed on each menu. Elaborated material here as a guide only, not really detailed, because the details in the description on the media manuscript.

\subsubsection{Media / Application Scripts}

To design a good and structured learning media should be prepared a guide or storyboard or script to design the media, including in making an application as a medium of learning. This script is used as a guide for the manufacture of camcorder simulator program. The writing of a media script starts from writing competency maps, material maps and GBIM. The above document is useful as a guide and the initial framework for creating a script. With these documents the resulting manuscript will be more structured.

In writing a camcorder simulator media/application script, the outline consists of 3 parts, namely: (a) Head of manuscript, (b) Display, (c) Description. Example display media script / application can be shown below: 

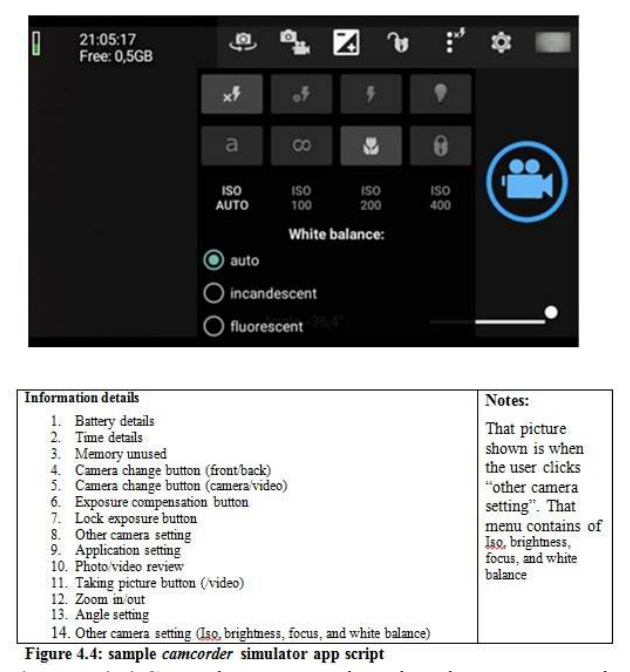

Figure 4.4 Sample camcorder simulator app script

\subsubsection{Production of Camcorder}

\section{Simulator Application}

In the development of camcorder simulator applications, researchers develop them in accordance with reference materials that have been prepared previously. The reference material begins with needs analysis, then compiles Competency Maps, Material Maps, Media Content Outline (GBIM), Material Journals, Flowcharts and Scripts. All reference materials are used as a controller of the development process so as not to deviate from the concept of early development so that the developed application remains focused to achieve the goals and competencies set.

Based on the design that has been compiled, the next step is to produce camcorder simulator applications using related software, in this case the main software used is android studio. Another software used is image processing software. Examples of camcorder simulator display design applications developed, can be seen in the following figure.

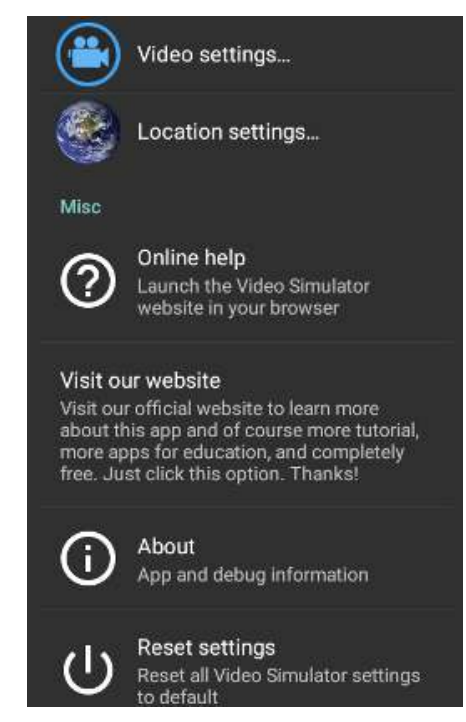

Figure 4.5: examples of camcorder simulator display design

An example of the creation of a combo-based simulator application combo android using android studio software can be viewed in the following picture:

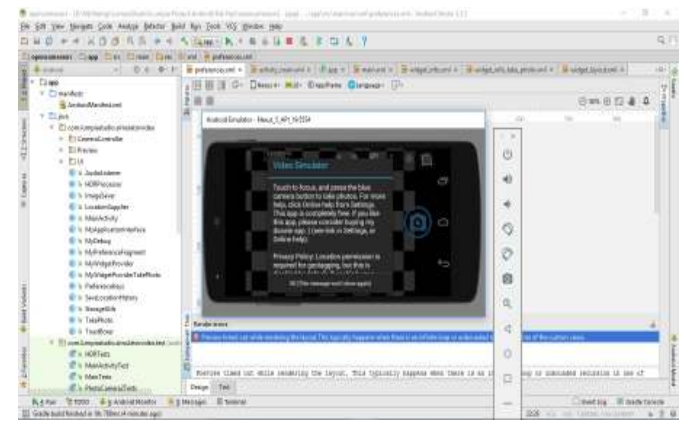

Figure 4.6: sample display of camcorder simulator application using android studio software

\subsection{Design Validation}

In order to know the reliability and performance of simulator application based on android video camera, the validation is conducted. Validation is conducted through several stages, started by the researchers themselves then continued by the media experts and material experts. Validation is done by the researcher to know that this application run functional. Another aim is to ensure every component in this application can function in accordance with the planned.

The next media validation stage is to test it to media experts and material experts. Aspects that are tested by media experts are aspects of software engineering and visual 
communication design aspects. Software engineering aspects include the following indicators: reliable, maintainable, reusable, accurate selection of application/ software/ tools for development, compatibility, program documentation, and reusable. The visual communication design aspects include: communicative; in accordance with the wishes of the target, creative, simple and alluring, audio, visual (layout design, typography, color), mobile media (animation, movie), and interactive layouts (navigation icons). The results of the assessment of media experts can be seen in the table below:

Table 4.2 Assessment of Media Experts

\begin{tabular}{cccccc}
\hline No & Variable & $\begin{array}{c}\text { Max } \\
\text { Sco } \\
\text { re }\end{array}$ & Score & Percentage & $\begin{array}{c}\text { Detail } \\
\text { s }\end{array}$ \\
\hline $\begin{array}{c}\text { Aspects of } \\
\text { software } \\
\text { engineering }\end{array}$ & 50 & 46 & $92 \%$ & $\begin{array}{r}\text { Very } \\
\text { good }\end{array}$ \\
\hline $\begin{array}{c}\text { Aspects of } \\
\text { visual } \\
\text { communication } \\
\text { design }\end{array}$ & 50 & 42 & $84 \%$ & $\begin{array}{c}\text { Very } \\
\text { good }\end{array}$ \\
\hline
\end{tabular}

The validation for the material specialist focuses on the design aspects of the lesson, which include the relevance of the learning objectives with the curriculum, the accuracy of the use of learning strategies, interactivity, the motivation of learning, contextuality and actuality, the appropriateness of the material to the learning objectives, the depth of matter, the ease of understanding, the systematic, clear, clarity of description, and simulation.

The results of the assessment of material experts can be seen in the table below.

Table 4.3 Material Expert Assessment

\begin{tabular}{cccccc}
\hline No & Variable & $\begin{array}{c}\text { Max } \\
\text { Sco } \\
\text { re }\end{array}$ & Score Percentage & $\begin{array}{c}\text { Detail } \\
\text { s }\end{array}$ \\
\hline 1 & $\begin{array}{c}\text { Aspects of } \\
\text { instructiona } \\
1 \text { design }\end{array}$ & $75 \%$ & 64 & $85 \%$ & $\begin{array}{c}\text { Very } \\
\text { good }\end{array}$ \\
\hline
\end{tabular}

\subsection{Design Revision}

Based on the results of media validation and material validation, researchers conducted an evaluation of the camcorder-based simulator application android. Once evaluated, then performed a revision process on some parts that became the record of the validator. So the application developed into a better product and ready to be utilized in the learning process of cinematography course.

\section{CONCLUSIONS}

In developing the design of camcorder android-based simulator model application for cinematography learning course, the researchers develop it according to the reference material that has been compiled before. The reference material begins with needs analysis, compiles competency maps, material maps, the Main Point of Media Content (GBIM), Material Journals, Flowcharts and Scripts. All reference materials are used as a controller of the development process so as not to deviate from the concept of early development. As a result, the developed application remains focused to achieve the goals and competencies set. The next process is to validate the media and validate the material to experts in the field, then revise the application based on the record of the validator. Ultimately, the application is ready for use.

\section{ACKNOWLEDGEMENTS}

I would like to thank all the students and lecturers of cinematography study program of Education Faculty, State University of Surakarta, especially Educational Technology Study Program who have participated and helped the implementation of this research.

\section{REFERENCES}

[1] Horwitz, Josh. (2014). Statistik Pengguna Internet Di Asia Dan Indonesia. Retrieved from http://Id.Techinasia.com. On 15th November 2015

[2] Kusuma, Aditya Candra. (2013). Perancangan Aplikasi Mobile Edukatif 'Belajar Chord Piano Untuk Pemula' Berbasis Android. STIMIK AMIKOM Yogyakarta

[3] Pasarai, Usman. (2010). Pengembangan dan Aplikasi Simulator Reservoir Untuk Simulasi Perkolasi Gas pada Reservoir Bertenaga Dorong Gas Terlarut. Lembaran publikasi Minyak dan Bumi Vol 44, No 3 (2010).

[4] Permadi, I Nyoman Agus. (2013). Pengembangan Aplikasi Game Simulasi Virtual Tingklik Dan Suling Bali Berbasis Android. KARMAPATI Journal Volume 2, No 6.

[5] Prameswari, Lourensia Palupi Dhika. (2009). Pengembangan Aplikasi Simulasi 
Mesin Mobil Berbasis Multimedia. UATY Yogyakarta.

[6] Purbasari, Rohmi Julia. (2013). pengembangan aplikasi android sebagai media pembelajaran matematika pada materi dimensi tiga untuk siswa SMK kelas X. UM Malang (jurnal-online.um.ac.id).

[7] Rusman, etal. (2013). Pembelajaran Berbasis Teknologi Informasi dan Komunikasi. Jakarta: Rajawali Pers.

[8] Sambodo, Riski Agung. (2014). Pengembangan Media Pembelajaran Mobile Learning (M-Learning) Berbasis Android pada Materi Sistem Peredaran Darah Manusia untuk Siswa Kelas XI SMA/MA. UIN Sunan Kalijaga Yogyakarta (Undergraduate Thesis).

[9] Soemapradja, Tomy G. (2014). Pengembangan Aplikasi Simulasi Perdagangan Saham Dengan Sector Rotation Dan Linear Programming. BINUS
BUSINESS REVIEW Vol. 5 No. 1 2014: 418-428.

[10] Sukmadinata, Nana Syaodih. (2016). Metode Penelitian Pendidikan. Bandung: Remaja Rosda Karya

[11] Sutanto, Arif Dwi. (2013). Perancangan Aplikasi Edukasi "Smart Brain Kids" Berbasis Android Sebagai Media Pembelajaran Untuk Anak Usia Dini. STIMIK AMIKOM Yogyakarta.

[12] Triluqman, Heri. (2017). Studi Kebutuhan Pengembangkan Aplikasi Simulator Kamera Video Berbasis Android di Program Studi Teknologi Pendidikan FIP UNNES. Proceeding of National Seminar"Pemanfaatan Smartphone untuk Literasi Produktif”. http://jurnal.fkip.uns.ac.id/index.php/psdtp/a rticle/view/10430

[13] Urip. (2011). Android, Sarana dan Sumber Alternatif Belajar Kimia. Retrieved from www.urip.wordpress.com. 